\title{
The Effect of Recombinant Growth Hormone Treatment in Children with Idiopathic Short Stature and Low Insulin-Like Growth Factor-1 Levels
}

\author{
Zeynep Şıklar, Pınar Kocaay, Emine Çamtosun, Mehmet Isakoca, Bülent Hacıhamdioğlu, \\ Şenay Savaş Erdeve, Merih Berberoğlu \\ Ankara University Faculty of Medicine, Department of Pediatric Endocrinology, Ankara, Turkey
}

\section{ABSTRACT}

Objective: Idiopathic short stature (ISS) constitutes a heterogeneous group of short stature which is not associated with an endocrine or other identifiable cause. Some ISS patients may have varying degrees of insulin-like growth factor-1 (IGF-1) deficiency. Recombinant growth hormone ( $\mathrm{rGH}$ ) treatment has been used by some authors with variable results. Reports on long-term rGH treatment are limited.

Methods: In this study, 21 slowly growing, non-GH-deficient ISS children who received rGH treatment for $3.62 \pm 0.92$ years were evaluated at the end of a $5.42 \pm 1.67$-year follow-up period. The study group included patients with low IGF-1 levels who also responded well to an IGF generation test. The patients were divided into two groups as good responders [height increment $>1$ standard deviation (SD)] and poor responders (height increment $<1 \mathrm{SD}$ ) at the end of the follow-up period.

Results: The height of the patients improved from $-3.16 \pm 0.46$ SD score (SDS) to $-1.9 \pm 0.66$ SDS. At the end of the follow-up period, mean height SDS was -1.72 . Eleven of the patients showed a good response to treatment. Clinical parameters were essentially similar in the good responders and the poor responders groups. A female preponderance was noted in the good responders group.

Recombinant growth hormone $(\mathrm{rGH})$ treatment has already been used in idiopathic short stature (ISS) children without GH deficiency. Insulin-like growth factor-I (IGF-I) deficiency accompanied some portion of the cases.

\section{WHAT THIS STUDY ADDS?}

Little information exists about the final height of ISS children with low IGF-I receiving rGH treatment. In this study, we investigated and presented our findings regarding the response to $\mathrm{rGH}$ and the final height in a group of ISS children with low IGF-I level.

Conclusion: rGH treatment can safely be used in ISS children. Long-term GH treatment will ameliorate the height deficit and almost $40 \%$ of patients may reach their target height.

Key words: Final height, growth hormone treatment, idiopathic short stature, insulin-like growth factor deficiency

Conflict of interest: None declared

Received: 14.05 .2015

Accepted: 06.09 .2015

Address for Correspondence

Zeynep Şıklar MD, Ankara University Faculty of Medicine, Department of Pediatric Endocrinology, Ankara, Turkey

Phone: +90 3123191440 E-mail: zeynepsklr@gmail.com

OJournal of Clinical Research in Pediatric Endocrinology, Published by Galenos Publishing. 
Sıklar Z et al.

Recombinant Growth Hormone Treatment in Idiopathic Short Stature Children with Low Insulin-Like Growth Factor-1 Levels

\section{Introduction}

An individual with idiopathic short stature (ISS) is defined as one with a height of more than 2 or 2.25 standard deviations (SDs) below the mean height for a particular age and sex, without any evidence of an underlying disorder $(1,2,3)$. Approximately $80 \%$ of individuals with short stature do not have an identified etiology and are therefore classified as ISS. Actually, ISS consists of a heterogeneous group of individuals with short stature, and a number of them may have some elements of growth hormone $(\mathrm{GH})$ /insulin-like growth factor-1 (IGF-1) axis abnormalities (4). Disorders of GH/IGF-1 axis are the most important factors affecting postnatal growth. While $\mathrm{GH}$ is the major regulator of circulating IGF-1 levels in healthy subjects, low IGF-1 levels can be seen with normal or high $\mathrm{GH}$ secretion and these cases are identified as IGF-1-deficient patients (5).

Although they show no evidence of endocrine or other causes of short stature, a small group of ISS patients have varying degrees of IGF-1 deficiency. The degree of IGF-1 deficiency in these children is usually less marked than that in severe $\mathrm{GH}$ deficiency or in classical severe primary IGF-1 deficiency (Laron syndrome) patients (6) These non-GHdeficient (non-GHD) short stature children with low IGF-1 also cannot attain a normal adult height (3).

In ISS children, the most effective treatment modalities for short stature are still under evaluation. $\mathrm{rGH}$ or rIGF-1 can be assumed to be an alternative in the treatment of these children. Recombinant human IGF-1 (rhIGF-1) treatment has been approved in only severe primary IGF-1 deficiency and had not been commercially available in most countries until very recently. Especially after the Food and Drug Administration (FDA) approval of GH for therapy in ISS in 2003, rGH has been used by different study groups $(3,4,7,8,9)$. While short-term studies demonstrated a benefit of $\mathrm{rGH}$ therapy, the effect on final height $(\mathrm{FH})$ and long-term results are limited and heterogeneous.

The aim of the current study was to determine the effect of $\mathrm{rGH}$ treatment, including long-term follow-up results, in ISS children with growth failure of unknown etiology and with IGF-1 levels below the -2 SDs of normal levels.

\section{Methods}

The study was approved by the Ethics Committees of the University and conducted in the Pediatric Endocrinology Clinic between 1998 and 2014. The study group consisted of children with ISS and only those with low IGF-1 levels. The diagnosis of ISS was based on the finding of a standing height of more than 2 SDs below the corresponding mean height for a particular age and sex without evidence of an underlying disorder.

Inclusion criteria were: 1) Presence of short stature (height SD below -2$)$ and/or low growth velocity $\left(<25^{\text {th }}\right.$ centile over
6 months of follow-up) for age and sex; 2) Adequate $\mathrm{GH}$ response to $\mathrm{GH}$ stimulation tests (peak $\mathrm{GH}>10 \mathrm{ng} / \mathrm{mL}$ ); 3) Low serum IGF-1 levels (<3th centile for age and sex); 4) Adequate IGF-1 response to IGF-1 generation tests (an increase of IGF-1 higher than 15 micrograms/L in the IGF generation test; and an increase of IGFBP-3 higher than $0.4 \mathrm{mg} / \mathrm{L}$ ); and 5) Receiving recombinant human $\mathrm{GH}$ therapy (10). Exclusion criteria were: (1) patients with identified causes of short stature (skeletal dysplasia, chronic diseases, chromosomal abnormalities, nutritional disorders) and those on any medication other than $\mathrm{GH}$, such as steroid therapy, and (2) children showing a normal velocity in growth.

Clinical characteristics including birth weight, height, weight, height SDS (HSDS), body mass index (BMI), and bone age at diagnosis were determined. SDS values for anthropometric data and BMI (weight $(\mathrm{kg}) /$ height $\left.(\mathrm{m})^{2}\right)$ were calculated using national data $(11,12)$. Treatment duration, height increment, and $\mathrm{FH}$ of patients were also evaluated. $\mathrm{FH}$ was defined as a state in which a height velocity ( $\mathrm{HtV}$ ) less than $0.5 \mathrm{~cm} / \mathrm{yr}$ had been attained (13).

Parent-adjusted height deficit was determined in all patients by calculation of differences between HSDS for chronological age and target HSDS (14).

Laboratory assessment included measurement of hematological, biochemical, and hormonal [thyroxine $\left(\mathrm{T}_{4}\right)$, thyroid-stimulating hormone (TSH), IGF-I, IGF-binding protein 3 (IGF-BP3), GH stimulation tests] parameters. Serum GH $(\mathrm{ng} / \mathrm{mL})$ levels were measured by immunoradiometric assay (IRMA) using an Immunotech ${ }^{\circledR}$ kit. IGF-I and IGFBP3 were assayed by IRMA using a DSL ${ }^{\circledR}$ kit.

A diagnosis of GHD was excluded by the findings of peak stimulated $\mathrm{GH}$ levels higher than $10 \mathrm{ng} / \mathrm{mL}$ in the insulin tolerance test and the L-dopa stimulation test. Blood samples were drawn from an indwelling catheter inserted in an antecubital vein. All tests were performed in the morning between 08:00-09:00 am after the patients had fasted overnight.

An IGF generation test was applied to patients with low IGF-1 levels who showed a low growth velocity (by age and sex), but who had a normal or high $\mathrm{GH}$ response to the $\mathrm{GH}$ stimulation test. The IGF-1 generation test was conducted by administering $\mathrm{rGH}$ in a dose of $0.033 \mathrm{mg} / \mathrm{kg} /$ day for four days (10).

In patients who showed an adequate $\mathrm{GH}$ response to the IGF generation test, $\mathrm{rGH}$ therapy was given in a dose of $0.2 \mathrm{mg} /$ $\mathrm{kg} /$ week. Improvement in height was assessed as delta HSDS (difference between HSDS at the start of the GH therapy and last HSDS). The duration of $\mathrm{GH}$ treatment, achieved $\mathrm{FH}$, and parent-adjusted height were evaluated in all patients. According to height improvement, the patients were divided into two groups as good responders to $\mathrm{GH}$ treatment $(\Delta \mathrm{HSDS}>1 \mathrm{SD})$ and poor responders to $\mathrm{GH}$ treatment $(\Delta \mathrm{HSDS}<1 \mathrm{SD}$ ).

$\mathrm{GH}$ treatment was discontinued after epiphyseal closure, as determined by bone age evaluation. 


\section{Statistical Analysis}

In addition to descriptive analysis, t-test and Mann-Whitney $U$ test were applied in the evaluation variables after checking the appropriateness for normal distribution. Categorical variables were compared using the chi-square test.

\section{Results}

During the 16 years of study period, 21 patients (10 girls, 11 boys) were evaluated. At admission, the mean age of the patients was $11.02 \pm 2.01$ years and their mean HSDS was $-3.16 \pm 0.46$ before $\mathrm{GH}$ treatment. Mean growth velocity was $2.83 \pm 0.56 \mathrm{~cm} /$ year (Table 1). All patients had low IGF-1 levels and peak $\mathrm{GH}$ response to $\mathrm{GH}$ stimulation test was $17.93 \pm 8.21$ $\mathrm{ng} / \mathrm{mL}$. Patients were given $0.2 \mathrm{mg} / \mathrm{kg} /$ week $\mathrm{rGH}$ for $3.62 \pm 0.92$ years. After cessation of $\mathrm{GH}$ therapy, they were followed-up for 1.8 years. Total follow-up period of patients was $5.42 \pm 1.67$ years. During this time, mean bone age increased from $8.38 \pm 2.25$ years to $16.2 \pm 2.3$ years.

The mean age of onset of puberty was $12.34 \pm 0.94$ years. Girls and boys did not differ in age of onset of puberty $(p=0.2)$. At onset of puberty, the mean HSDS was $-2.77 \pm 0.61$ SDS. There were no subjects with delayed puberty among the patients included in the study.

After the period of $\mathrm{rGH}$ treatment, the patients were evaluated with respect to their height increment. At the end of the therapy, mean HSDS was $-1.9 \pm 0.66$. At the last examination, the total height increment was found to be 1.4 \pm 0.1.19 SD (Table 1). Parent-adjusted height deficit was $-2.35 \pm 0.35 \mathrm{SD}$ at the beginning of $\mathrm{GH}$ therapy, and there were no differences between the good responder and poor responder groups. When patients reached their $\mathrm{FH}$, the poor responders showed a greater parent-adjusted height deficit than the good responders (Table 2).

When the patients were evaluated for attainment of their target height (or according to their parent-adjusted height deficit), 8 patients were found to have reached an adult height within \pm 1 SD of their target height. Only one patient showed a FH SDS greater than +1 SDS from his target HSDS. FH SDS values were lower than $1 \mathrm{SD}$ of target HSDS in 12 patients (Figure 1).

Height improvement was greater than 1 SD in 11 patients (good responders). The remaining 10 patients showed a height increment less than $1 \mathrm{SD}$ (poor responder). There were no statistical differences between the groups of good responders and poor responders with respect to birth weight, age of diagnosis, bone age at diagnosis, target height, peak $\mathrm{GH}$ in response to $\mathrm{GH}$ stimulation, increment in IGF-1 levels to IGF generation test, duration of $\mathrm{GH}$ treatment, age of onset of

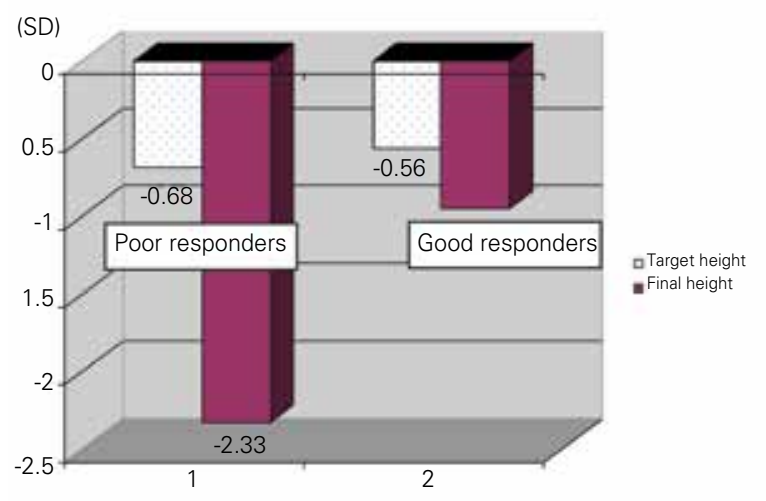

Figure 1. Target height and final height in the poor responder and good responder groups

Table 1. Characteristics of patients with good and poor response to growth hormone treatment

\begin{tabular}{|l|l|l|l|l|}
\hline & $\begin{array}{l}\text { Good responders } \\
\text { (>1 SD height increment) }\end{array}$ & $\begin{array}{l}\text { Poor responders } \\
\text { (<1 SD height increment) }\end{array}$ & Total & $\mathbf{p}$-value \\
\hline Female/Male & $8 / 3$ & $3 / 7$ & $11 / 10$ & $<0.5$ \\
\hline Age at diagnosis (years) & $11.31 \pm 1.98$ & $10.84 \pm 2.2$ & $11.02 \pm$ & 0.159 \\
\hline HSDS at diagnosis & $-3.19 \pm 0.51$ & $-2.98 \pm 0.38$ & $-3.16 \pm 0.46$ & 0.106 \\
\hline Target HSDS & $-0.56 \pm 0.72$ & $-0.68 \pm 0.8$ & $-0.62 \pm 0.74$ & $\mathbf{0 . 0 0 7}$ \\
\hline $\begin{array}{l}\text { Parent-adjusted height deficit at diagnosis } \\
\text { (SD) }\end{array}$ & $-2.55 \pm 0.89$ & $-2.16 \pm 0.82$ & $-2.35 \pm 0.85$ & 0.159 \\
\hline Peak GH (ng/mL) & $17.75 \pm 6.31$ & $18.6 \pm 10.16$ & $17.93 \pm 8.21$ & 0.33 \\
\hline $\begin{array}{l}\text { Increment of IGF-1 in response to IGF-1 } \\
\text { generation test (\%) }\end{array}$ & $135.55 \pm 53.79$ & $224.05 \pm 164.9$ & $186.2 \pm 92.6$ & 0.09 \\
\hline IGF-1 SDS & & & $-2.8 \pm 0.48$ & 0.22 \\
\hline Bone age at diagnosis (years) & $-2.62 \pm 0.52$ & $-2.9 \pm 0.44$ & $8.28 \pm 2.25$ & 0.142 \\
\hline BMI SDS & $9.35 \pm 1.79$ & $8.22 \pm 2.57$ & $-1.11 \pm 0.88$ & 0.26 \\
\hline GH: growth hormone, SDS: standard deviation score, IGF-1: insulin-like growth factor-1, BMI SDS: body mass index standard deviation score, HSDS: height standard deviation score \\
\hline
\end{tabular}


Sıklar Z et al.

Recombinant Growth Hormone Treatment in Idiopathic Short Stature Children with Low Insulin-Like Growth Factor-1 Levels

Table 2. Characteristics of patients with good and poor response to growth hormone treatment

\begin{tabular}{|l|l|l|l|l|}
\hline & $\begin{array}{l}\text { Good responders } \\
\text { (>1 SD height increment) }\end{array}$ & $\begin{array}{l}\text { Poor responders } \\
\text { (<1 SD height increment) }\end{array}$ & Total & p-value \\
\hline Age at NFH (years) & $15.03 \pm 1.62$ & $14.97 \pm 1.01$ & $15 \pm 1.3$ & 0.48 \\
\hline Duration of GH treatment (years) & $3.3 \pm 0.98$ & $4.12 \pm 2.6$ & $3.62 \pm 0.92$ & 0.14 \\
\hline IGF-1 SD & $-1.56 \pm 0.64$ & $-2.01 \pm 0.89$ & $-1.7 \pm 0.77$ & 0.06 \\
\hline HSDS at NFH & $-1.55 \pm 0.51$ & $-2.44 \pm 0.56$ & $-1.9 \pm 0.66$ & 0.002 \\
\hline Delta HSDS at NFH & $1.47 \pm 1.02$ & $0.48 \pm 0.99$ & $1.4 \pm 1.19$ & 0.0003 \\
\hline $\begin{array}{l}\text { Follow-up time after cessation of GH } \\
\text { therapy (years) }\end{array}$ & $1.85 \pm 1.47$ & $1.76 \pm 1.49$ & $1.8 \pm 1.43$ & 0.26 \\
\hline Age of attainment of FH (years) & $16.37 \pm 1.62$ & $16.22 \pm 1.01$ & $16.34 \pm 1.3$ & 0.23 \\
\hline Parent-adjusted height deficit at FH (SDS) & $-0.34 \pm 1.02$ & $-1.65 \pm 0.99$ & $-1.02 \pm 1.19$ & $\mathbf{0 . 0 0 3}$ \\
\hline FH SD & $-0.95 \pm 0.81$ & $-2.33 \pm 0.7$ & $-1.72 \pm 1.04$ & $\mathbf{0 . 0 0 0 1}$ \\
\hline BMI SDS & $0.44 \pm 1.03$ & $-0.24 \pm 0.54$ & $0.11 \pm 0.88$ & $\mathbf{0 . 0 4 6}$ \\
\hline
\end{tabular}

GH: growth hormone, SDS: standard deviation score, FH: final height, NFH: near-final height, IGF-1: insulin-like growth factor-1, BMI SDS: body mass index standard deviation score

puberty, HSDS at onset of puberty, and age of GH cessation. Female preponderance was observed among the good responders (73\% vs. 30\%) (Table 2). Only two patients were small for gestational age, one each in the good responders and the poor responders groups.

Age of onset of puberty was similar in the poor responders $(12.58 \pm 1.09$ years) and good responders $(12.09 \pm 0.77$ years) groups $(p=0.17)$. Also, HSDS at onset of puberty was not statistically different between the two groups. Mean HSDS of the poor responders was $-2.61 \pm 0.64$, while that of the good responders group was $-3.13 \pm 0.44(p=0.05)$.

At the cessation of GH therapy, the HSDS of the good responders group was $-1.65 \pm 1.47$, while this value was $-2.44 \pm 0.46$ SDS in the poor responders.

When defining the parent-adjusted height deficit as lower than 1 SDS, only two patients in the poor responders group were able to reach an acceptable target HSDS.

At the onset of the study, the mean BMI SDS of the study group was $-1.11 \pm 1.09$. At the end of the follow-up, it increased to $0.11 \pm 0.88(p=0.0002)$. While there was no differences between the BMI SDS values of the poor responders and those of the good responders initially, good responders showed a greater increase in BMI SDS after treatment than poor responders (Table 1, 2).

\section{Discussion}

The underlying abnormalities in ISS children may be associated with abnormalities affecting the integrity of the $\mathrm{GH}$ receptor or signal transduction pathway, a state which may have compromised the sensitivity to $\mathrm{GH}$ (4). There may be a spectrum of $\mathrm{GH}$ insensitivity ranging from mild, as in some ISS patients, to severe, as in the Laron syndrome (4). In rare cases, ISS is due to molecular abnormalities of IGF Some researchers suggest that an overlap exists between ISS patients and those with partial or atypical GH insensitivity (15). Of all ISS patients, IGF-1 deficient patients constitute a very small group and they may have some degree of $\mathrm{GH}$ insensitivity. Excluding the severe IGF deficiency cases, the prevalence of mild IGF deficiency in ISS children is not well-known. In a French cohort study, the prevalence of severe primary IGF deficiency was reported as $2.5 \%$ among the ISS children (7). In another study of prepubertal children with isolated short stature below or equal to -2.5 SDS, the prevalence of IGF deficiency has been reported as $0.8 \%$ (16).

We evaluated a selected subgroup of IGF-1 deficient ISS children who showed an adequate response to a $\mathrm{GH}$ stimulation test and also an adequate response to a IGF-1 generation test, indicating that they could benefit from $\mathrm{rGH}$ treatment. Although there are reports on $\mathrm{GH}$ treatment in ISS children, the definition of short stature (below -2, -2.25,-2.5,-3 SDS), of IGF-1 levels (normal, -2 SDS, -3 SDS), the doses of $\mathrm{GH}$, etc. were heterogeneous in these studies. Overall, these studies reported good responses to $\mathrm{GH}$ in these children $(7,8,9,16,17,18)$.

In our patients, after treatment with $\mathrm{GH}$ for a mean period of 3.62 years, HSDS increased from $-3.16 \mathrm{SD}$ to $-1.9 \mathrm{SD}$. Treatment with rGH was well-tolerated. It did not significantly accelerate bone maturation and no overall side effects were seen. To date, rGH treatment in GHD as well as in non-GHD children has shown a good safety and efficiency profile (19).

While short-term studies showed an approximately +0.7 SD HSDS increment over one year, adult height studies suggested a height gain of 0.57 SD in ISS children treated with $\mathrm{GH}$ (20). However, the studies on ISS are quite heterogeneous. Many of these studies have been conducted on groups including both IGF-1-deficient ISS children and short children with normal IGF-1 levels. However, although the doses used 
Şılar Z et al.

Recombinant Growth Hormone Treatment in Idiopathic Short Stature Children with Low Insulin-Like Growth Factor-1 Levels

and the characteristics of patients were not similar in all these studies, FH of ISS children treated with $\mathrm{GH}$ was reported to be 0.6 SDS and 0.5 SDS greater than the control groups $(15,19)$. A meta-analysis consisting of reports on controlled studies up to $\mathrm{FH}$ in children with ISS showed a mean height difference of 0.65 SDS from that of the controls (18).

ISS patients do not show a unique response to $\mathrm{GH}$ treatment. Even in GHD patients, there was no uniform response to $\mathrm{GH}$. The sensitivity of individual patients to treatment can be different. Some ISS patients showed a good response, unlike others who did not respond well $(4,21)$. We grouped our patients as good responders and poor responders according to their height improvement. We attempted to rule out poor compliance with scheduled $\mathrm{GH}$ injections by asking the families to return empty used cartridges and asking about any misinjection day at every visit. There were no statistical differences between the two groups with respect to birth weight, chronological age at presentation, HSDS at admission, bone age at diagnosis, target height, peak $\mathrm{GH}$ to $\mathrm{GH}$ stimulation test, increment in IGF-1 levels in response to the IGF generation test, duration of GH treatment, age of onset of puberty, HSDS at puberty onset, and age when GH treatment was stopped. However, a preponderance of girls was noted in the good responders group, as opposed to that in the poor responders group.

Although the parameters for predicting long-term response to $\mathrm{GH}$ in ISS have not been established, some studies showed that greater height gain was associated with a lower baseline HSDS, a lower baseline IGF-1 level, a lower pretreatment $\mathrm{HtV}$, and with a greater delay in bone age (15). In fact, the characteristics of etiological factors leading to ISS could be predictive for response to GH therapy. In ISS patients with a defect of GHR, the response can be lower than that of patients with a disorganized pattern of $\mathrm{GH}$ release (22).

ISS can be accompanied by familial short stature and/or constitutional delay of growth and puberty (CGDP) in some patients (23). Some authors have suggested that children with ISS who responded more vigorously to $\mathrm{rGH}$ probably have CGDP (23). In our cases, puberty was not delayed in both good responder and poor responder groups. So, the effect of CGPD does not seem to be a component of short stature in these patients.

Groups were not equal according to sex. The rate of female patients was higher in good responders than in poor responders. In other words, we can say that poor response was more frequent in male patients. We could not explain this difference between female and male patients. However, this result may not be conclusive and may have been related to the relative smallness of our sample.

The familial components of short stature were also evaluated in our patients. Mean target HSDS was -0.62 and there was no difference between the two groups. Only one patient had a target height lower than -2 SD, and this patient belonged to the poor responders group. Except for this patient, it could not be said that an additional familial component of short stature was found in this study.

At $\mathrm{FH}$ evaluation, 9 patients (43\%) were found to have reached or exceeded their target height. As expected, these patients were mostly in the good responders group. It can be suggested that an important part of slowly growing ISS patients with low IGF-1 levels may show a good response to rGH therapy.

We used a fixed dose of $0.2 \mathrm{mg} / \mathrm{kg} /$ week of $\mathrm{GH}$ in our patients. An IGF-1 based $\mathrm{GH}$ dosing could be an alternative treatment in patients in the poor responders group. In one study on non-GHD subjects with significant short stature and different IGF-I levels, adjusting the $\mathrm{GH}$ dose to achieve an IGF-I level in the mid-to-upper normal range has resulted in a significant increase in HSDS at 12 months and has been welltolerated (3). The authors have concluded that this approach used mean $\mathrm{GH}$ doses within FDA-approved ranges for patients with ISS and allowed for optimized height gain, compared with standard fixed doses of $\mathrm{GH}$ in children with ISS.

One other aim of our study was to elucidate the possibilities of our patients having monogenic causes of short stature. Unfortunately, we had no possibility to make molecular genetic analysis in our patients. Monogenic causes of short stature which are associated with a low serum IGF-I level and normal or high $\mathrm{GH}$ levels could comprise the defects of $\mathrm{GH} 1$ (bioinactive $\mathrm{GH}), \mathrm{GHSR}$ (ghrelin receptor), GHR (GH receptor), STAT5B, IGF1, and IGFALS (24). In one study, heterozygous STAT5B mutations, with or without heterozygous IGFALS defects were shown to be present in short children with $\mathrm{GH}$ insensitivity. In the same study, functional variants were found in children with less severe short stature or IGF-I deficiency (24). In the future, with advancing molecular genetic studies, it will be possible to reveal the underlined etiological factors of ISS patients.

In conclusion, our study shows that slowly growing ISS children with IGF deficiency can respond well to rGH treatment. Knowing underlying molecular abnormalities in ISS patients could be helpful for planning the treatment in many, if not all, cases. Especially if there is no opportunity to make advanced molecular genetic analysis in non-GHD short children with IGF deficiency, rGH treatment can be beneficial. In this situation, long-term GH treatment will ameliorate height deficit, and almost $40 \%$ of patients will be able to reach their target height.

\section{Authorship Contributions}

Ethics Committee Approval: Ankara University Ethics Committee (Approval number: 18-761-14), Informed Consent: It was taken, Concept: Zeynep Şıklar, Design: Zeynep Şıklar, Data Collection or Processing: Zeynep Şıklar, Pınar Kocaay, Emine Çamtosun, Mehmet Isakoca, Bülent Hacıhamdioğlu, Şenay Savaş Erdeve, Analysis or Interpretation: Zeynep Şıklar, Merih Berberoğlu, Literature Search: Zeynep Şıklar, Writing: Zeynep Şıklar, Merih Berberoğlu, Peer-review: Externally peerreviewed, Financial Disclosure: The authors declared that this study has received no financial support. 
Sıklar Z et al.

Recombinant Growth Hormone Treatment in Idiopathic Short Stature Children with Low Insulin-Like Growth Factor-1 Levels

\section{References}

1. Cohen $P$, Rogol $A D$, Deal $C L$, Saenger $P$, Reiter $E O$, Ross JL, Chernausek SD, Savage MO, Wit JM; 2007 ISS Consensus Workshop participants. Consensus statement on the diagnosis and treatment of children with idiopathic short stature: a summary of the Growth Hormone Research Society, the Lawson Wilkins Pediatric Endocrine Society, and the European Society for Paediatric Endocrinology Workshop. J Clin Endocrinol Metab 2008;93:4210-4217. Epub 2008 Sep 9

2. Collett-Solberg PF. Update in growth hormone therapy of children. J Clin Endocrinol Metab 2011;96:573-579.

3. Cohen $P$, Rogol AD, Weng W, Kappelgaard AM, Rosenfeld RG, Germak J; American Norditropin Study Group. Efficacy of IGF-based growth hormone $(\mathrm{GH})$ dosing in nonGH-deficient (nonGHD) short stature children with low IGF-I is not related to basal IGF-I levels. Clin Endocrinol (Oxf) 2013;78:405-414.

4. Park P, Cohen P. Insulin-like growth factor I (IGF-I) measurements in growth hormone $(\mathrm{GH})$ therapy of idiopathic short stature (ISS). Growth Horm IGF Res 2005;15(Suppl A):13-20.

5. Cohen J, Blethen S, Kuntze J, Smith SL, Lomax KG, Mathew PM. Managing the child with severe primary insulin-like growth factor-1 deficiency (IGFD): IGFD diagnosis and management. Drugs R D 2014;14:25-29.

6. Savage MO, Camacho-Hübner C, David A, Metherell LA, Hwa V, Rosenfeld RG, Clark AJ. Idiopathic short stature: will genetics influence the choice between GH and IGF-I therapy? Eur J Endocrinol 2007:157(Suppl 1):33-37.

7. Teissier R, Flechtner I, Colmenares A, Lambot-Juhan $K$, Baujat G, Pauwels C, Samara-Boustani D, Beltrand J, Simon A, Thalassinos C, Crosnier H, Latrech H, Pinto G, Le Merrer M, Cormier-Daire V, Souberbielle JC, Polak M. Characterization and prevalence of severe primary IGF1 deficiency in a large cohort of French children with short stature. Eur J Endocrinol 2014;170:847-854. Epub 2014 Mar 24

8. Wit JM, Rekers-Mombarg LT; Dutch Growth hormone Advisory Group. Final height gain by $\mathrm{GH}$ therapy in children with idiopathic short stature is dose dependent. J Clin Endocrinol Metab 2002;87:604-611.

9. Hintz RL. Growth hormone treatment of idiopathic short stature: clinical studies. Growth Horm IGF Res 2005;15(Suppl A):6-8.

10. Blum WF, Cotterill AM, Postel-Vinay MC, Ranke MB, Savage $\mathrm{MO}$, Wilton P. Improvement of diagnostic criteria in growth hormone insensitivity syndrome: solutions and pitfalls. Pharmacia Study Group on Insulin-like Growth Factor I Treatment in Growth Hormone Insensitivity Syndromes. Acta Paediatr Suppl 1994;399:117-124.

11. Bundak R, Furman A, Gunoz H, Darendeliler F, Bas F, Neyzi $\mathrm{O}$. Body mass index references for Turkish children. Acta Paediatr 2006;95:194-198.

12. Neyzi O, Furman A, Bundak R, Gunoz H, Darendeliler F, Bas F. Growth references for Turkish children aged 6-18 years. Acta Paediatr 2006;95:1635-1641.

13. Bundak R, Darendeliler F, Günöz $H$, Baş F, Saka N, Neyzi O. Puberty and pubertal growth in healthy Turkish girls: no evidence for secular trend. J Clin Res Pediatr Endocrino 2008;1:8-14. Epub 2008 Aug 2
14. Radetti G, D'Addato G, Gatti D, Bozzola M, Adami S. Influence of two different $\mathrm{GH}$ dosage regimens on final height, bone geometry and bone strength in $\mathrm{GH}$-deficient children. Eur $\mathrm{J}$ Endocrinol 2006;154:479-482.

15. Pedicelli S, Peschiaroli E, Violi E, Cianfarani S. Controversies in the definition and treatment of idiopathic short stature (ISS). J Clin Res Pediatr Endocrinol 2009;1:105-115. Epub 2009 Feb 1

16. Edouard T, Grünenwald S, Gennero I, Salles JP, Tauber M. Prevalence of IGF1 deficiency in prepubertal children with isolated short stature. Eur J Endocrinol 2009;161:43-50.Epub 2009 May 5

17. Leschek EW, Rose SR, Yanovski JA, Troendle JF, Quigley CA, Chipman JJ, Crowe BJ, Ross JL, Cassorla FG, Blum WF, Cutler GB Jr, Baron J; National Institute of Child Health and Human Development-Eli Lilly \& Co. Growth Hormone Collaborative Group. Effect of growth hormone treatment on adult height in peripubertal children with idiopathic short stature: a randomized, double-blind, placebo-controlled trial. $\mathrm{J}$ Clin Endocrinol Metab 2004;89:3140-3148.

18. Kemp SF, Kuntze J, Attie KM, Maneatis T, Butler S, Frane J, Lippe B.Efficacy and safety results of long-term growth hormone treatment of idiopathic short stature. J Clin Endocrinol Metab 2005;90:5247-5253. Epub 2005 Jul 5

19. Albertsson-Wikland K, Aronson AS, Gustafsson J, Hagenäs $L$, Ivarsson SA, Jonsson B, Kriström B, Marcus C, Nilsson KO, Ritzén EM, Tuvemo T, Westphal O, Aman J. Dose-dependent effect of growth hormone on final height in children with short stature without growth hormone deficiency. J Clin Endocrinol Metab 2008;93:4342-4350. Epub 2008 Aug 26

20. Bryant J, Baxter L, Cave CB, Milne R. Recombinant growth hormone for idiopathic short stature in children and adolescents. Cochrane Database Syst Rev 2007;CD004440.

21. Cohen P, Germak J, Rogol AD, Weng W, Kappelgaard AM, Rosenfeld RG; American Norditropin Study Group. Variable degree of growth hormone $(\mathrm{GH})$ and insulin-like growth factor (IGF) sensitivity in children with idiopathic short stature compared with $\mathrm{GH}$-deficient patients: evidence from an IGF-based dosing study of short children. J Clin Endocrinol Metab 2010;95:2089-2098. Epub 2010 Mar 5

22. Rogol AD, Blethen SL, Sy JP, Veldhuis JD. Do growth hormone $(\mathrm{GH})$ serial sampling, insulin-like growth factor-I (IGF-I) or auxological measurements have an advantage over $\mathrm{GH}$ stimulation testing in predicting the linear growth response to GH therapy? Clin Endocrinol (Oxf) 2003;58:229237.

23. Elder CJ, Barton JS, Brook CG, Preece MA, Dattani MT, Hindmarsh PC. A randomised study of the effect of two doses of biosynthetic human growth hormone on final height of children with familial short stature. Horm Res 2008;70:8992. Epub 2008 Jun 12

24. Wit JM, van Duyvenvoorde HA, Scheltinga SA, de Bruin S, Hafkenscheid L, Kant SG, Ruivenkamp CA, Gijsbers AC, van Doorn J, Feigerlova E, Noordam C, Walenkamp MJ, Claahsen-van de Grinten H, Stouthart P, Bonapart IE, Pereira AM, Gosen J, Delemarre-van de Waal HA, Hwa V, Breuning $\mathrm{MH}$, Domené HM, Oostdijk W, Losekoot M. Genetic analysis of short children with apparent growth hormone insensitivity. Horm Res Paediatr 2012;77:320-333. Epub 2012 Jun 6 